\title{
PENDUGAAN UMUR SIMPAN SIRUP BUAH TIN "KHAROMAH" DENGAN METODE ACCELERATED SHELF LIFE TESTING (ASLT)
}

\author{
[Shelf Life Prediction of "Kharomah" Figs Syrup Using Accelerated Shelf Life Testing (ASLT) Methods]
}

\author{
Ali Mursyid Wahyu Mulyono*, Afriyanti, Joko Setyo Basuki, Sri Sukaryani \\ * Fakultas Pertanian, Universitas Veteran Bangun Nusantara Sukoharjo \\ *email: alimursyid wm@yahoo.com
}

Diterima 12 Januari 2018/ Disetujui 20 April 2018

\begin{abstract}
Pokoh Kidul is the center of figs plant in Wonogiri area. Figs was processed into syrup with "Kharomah" as brand by Posdaya Lancar Barokah. But, the shelf life of this syrup was not yet known. Therefore, the purpose of this study was to determine the shelf life of this syrup by the Accelerated Shelf Life Testing (ASLT) method. Product was saved at temperature of $5^{\circ} \mathrm{C}, 30^{\circ} \mathrm{C}$ and $50^{\circ} \mathrm{C}$ for 28 days. Every 7 days, a sample was taken and then the color, $\mathrm{pH}$ and reducing sugar was analysed. The lowest activation energy was obtained from the analysis of reducing sugar changes, it is $287,55 \mathrm{~mol} / \mathrm{cal}$. The shelf life of figs syrup at room temperature was 19 days, and 22 days at low temperature.
\end{abstract}

Keywords: ASLT, figs, shelf life, syrup

\section{ABSTRAK}

Desa Pokoh Kidul merupakan sentra tanaman buah tin di daerah Wonogiri. Buah tin yang dihasilkan selama ini diolah menjadi sirup buah tin dengan merk "Kharomah" oleh Posdaya Lancar Barokah. Akan tetapi, belum diketahui umur simpan dari sirup ini. Oleh karena itu, tujuan dari penelitian ini untuk mengetahui umur simpan sirup buah tin dengan metode Accelerated Shelf Life Testing (ASLT). Metode penelitian yang digunakan yaitu dengan penyimpanan produk sirup pada tiga suhu yang berbeda yaitu $5^{0}, 30^{\circ}$ dan $50^{\circ} \mathrm{C}$ selama 28 hari. Setiap 7 hari sekali diambil sampel dan dilakukan analisis warna, $\mathrm{pH}$ dan kadar gula reduksi. Energi aktivasi terendah didapatkan dari hasil analisis perubahan kadar gula reduksi yaitu 287,55 mol/kal. Umur simpan sirup buah tin di suhu ruang selama 19 hari, sedangkan di suhu rendah selama 22 hari.

Kata kunci: ASLT, buah tin, sirup, umur simpan

\section{PENDAHULUAN}

Desa Pokoh Kidul merupakan sentra buah tin di Wonogiri. Buah tin merupakan salah satu jenis buah yang mudah rusak sehingga perlu penanganan atau pengolahan pasca panen yang tepat. Saat panen melimpah, buah tin ini diolah menjadi sirup buah tin. Hal ini bertujuan untuk meningkatkan nilai jual dan umur simpan. Sirup buah tin dengan merk "Kharomah" diproduksi oleh Posdaya Lancar Barokah desa Pokoh Kidul Wonogiri.

Sirup buah tin "Kharomah" merupakan produk yang tidak tahan lama, tetapi belum diketahui dengan jelas umur simpannya. Selama ini penentuan umur simpan hanya berdasarkan pengalaman produsen saja, yaitu selama 4 bulan. Beberapa produk sirup sejenis memiliki umur simpan yang relatif pendek seperti sirup temulawak dengan umur simpan 45 hari (Suwita dkk, 2012), sirup buah pala selama 34 hari (Aryani, 2013), sari wortel nanas selama 25 hari (Pratiwi, 2009), sirup buah semu jambu mete selama 48 hari (Afriyanti dan Asmoro, 2017) dan sari akar alang-alang selama 41 hari (Anagari dkk, 2011).

Keterangan umur simpan suatu produk pangan wajib dicantumkan pada kemasan oleh produsen, untuk manjamin produk aman sampai ke tangan konsumen. Selain itu, pencantuman masa kadaluarsa akan meningkatkan kenyamanan dan keamanan konsumen dalam mengkonsumsi produk tersebut. Kewajiban pencantuman masa kadaluarsa pada label pangan diatur dalam Undang-undang Pangan no.7/1996 serta Peraturan Pemerintah No. 69/1999 tentang Label dan Iklan Pangan.

Metode-metode dalam penentuan umur simpan adalah Literature Value, Distribution Turn Over, Distribution Abuse Test, Consumer Complaints dan Accelerated Shelf Life Testing (ASLT). Penelitian umur simpan sirup buah semu jambu mete ini menggunakan metode Accelerated Shelf Life Testing (ASLT). Metode ini menggunakan 
Versi Online:

http://www.profood.unram.ac.id/index.php/profood e-ISSN: 2443-3446

kondisi suatu kondisi lingkungan yang dapat mempercepat terjadinya reaksi-reaksi penurunan mutu produk pangan (Labuza, 1982). Waktu pengujian yang dilakukan relatif singkat tetapi keakuratan dan akurasinya tinggi. Selanjutnya digunakan pendekatan Arrhenius sebagai persamaan untuk memperhitungkan perubahan energi aktivasi. Hasil akhir akan diperoleh umur simpan pada suhu ruang yaitu $27^{\circ} \mathrm{C}$ (Anagari dkk, 2011)

Tujuan dari penelitian ini adalah untuk mengetahui umur simpan produk sirup yang selama ini telah diproduksi oleh Posdaya Lancar Barokah sehingga akan meningkatkan tingkat kepercayaan konsumen terhadap sirup yang akan mereka konsumsi.

\section{METODOLOGI}

\section{Bahan}

Bahan baku yang digunakan adalah sirup buah Tin merk "Kharomah" yang diproduksi oleh Posdaya Lancar Barokah Pokoh Wonogiri.

\section{Tahapan Penelitian}

Sirup yang sudah siap kemas dibagi dalam 26 botol untuk persiapan analisis. Sebanyak 8 botol disimpan dalam suhu $5^{\circ} \mathrm{C}, 8$ botol disimpan dalam suhu $30^{\circ} \mathrm{C}$ dan 8 botol disimpan dalam suhu $50^{\circ} \mathrm{C}$ dan 2 botol sebagai kontrol. Sebelum penyimpanan dilakukan pengukuran $\mathrm{pH}$, uji warna, dan uji mikrobiologi dengan metode TPC. Hasilnya digunakan sebagai kontrol. Setiap 7 hari sekali dilakukan sampling untuk dilakukakan analisis seperti pada kontrol.

Analisis yang dilakukan yaitu analisis warna dilakukan dengan Metode Hunter menggunakan alat chromameter (Hutching, 1999), analisis $\mathrm{pH}$ dengan $\mathrm{pH}$ meter yang terlebih dahulu dikalibrasi oleh buffer $\mathrm{pH} 4$ dan 7 (AOAC, 1995) dan kadar gula metode Nelson Somogyi (Apriantono, 1989).

Hasil yang diperoleh dari penelitian ini kemudian dianalisis dengan menggunakan metode ASLT dengan model Arrhenius (Pranoto, 2012). Persamaan model Arrhenius adalah sebagai berikut :

$k=k_{0} \cdot e^{-E a / R T}$

keterangan :

$\mathrm{k}=$ konstanta penurunan mutu

k。 = konstanta (tidak bergantung pada suhu)

Ea = energi aktivasi $(\mathrm{Kal} / \mathrm{mol})$
Pro Food (Jurnal Ilmu dan Teknologi Pangan)

Vol 4 No. 1 Mei 2018

ISSN: 2443-1095

$\mathrm{T}=$ suhu mutlak ( $\left.{ }^{\circ} \mathrm{K}\right)$

$\mathrm{R}=$ konstanta gas $(1,986 \mathrm{Kal} / \mathrm{mol} \mathrm{K})$

Dengan mengubah persamaan tersebut di atas maka menjadi :

$\ln \mathrm{k}=\ln \mathrm{k}_{0}-\underline{\mathrm{Ea}}$

RT

Hasil yang diperoleh selanjutnya diplotkan pada grafik hubungan antara lama penyimpanan (hari) dan rata-rata penurunan nilai mutu/hari (k). Langkah berikutnya adalah menentukan regresi linearnya. Setelah diperoleh persamaan regresi untuk masingmasing suhu penyimpanan, dibuat plot Arrhenius dengan sumbu $x$ menyatakan $1 / T$ dan sumbu $y$ menyatakan In $k$. oK menunjukkan slope dari regresi linear yang didapat dari ketiga suhu penyimpanan yang digunakan. Selanjutnya umur simpan produk dapat dihitung berdasarkan persamaaan :

Perkiraan umur simpan ( $\mathrm{t})=\frac{\text { Total wnit mutu }}{\text { Penurunan mutu }}$

\section{HASIL DAN PEMBAHASAN}

Bahan baku yang digunakan dalam penelitian ini adalah sirup buah tin merk "Kharomah" yang diproduksi oleh Posdaya Lancar Barokah Pokoh Wonogiri. Proses produksi dengan teknologi yang sederhana menghasilkan produk dengan kualitas yang kurang optimal. Selain itu buah tin yang digunakan belum matang optimal sehingga kandungan fenol dalam produk sirup pun masih rendah.

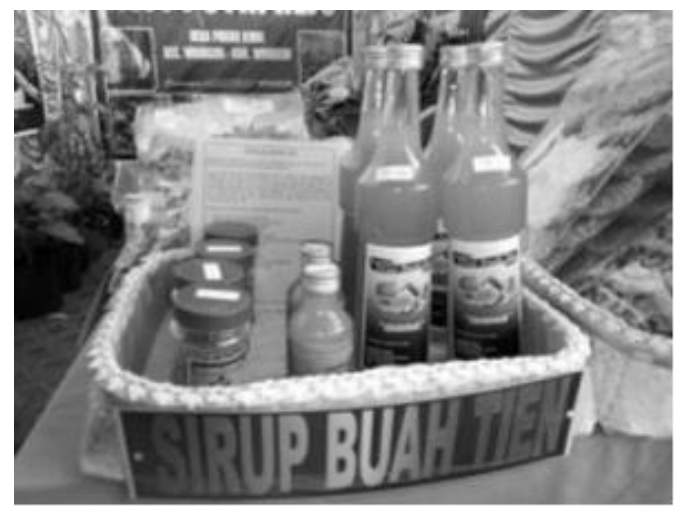

Gambar 1. Sirup buah tin "Kharomah" (Riyadi dan Bharsela, 2018)

\section{Analisis Warna}

Hasil analisis warna sirup dengan tiga suhu penyimpanan yang berbeda selama 28 hari dapat dilihat pada Gambar 2. 
Versi Online:

http://www.profood.unram.ac.id/index.php/profood e-ISSN: 2443-3446

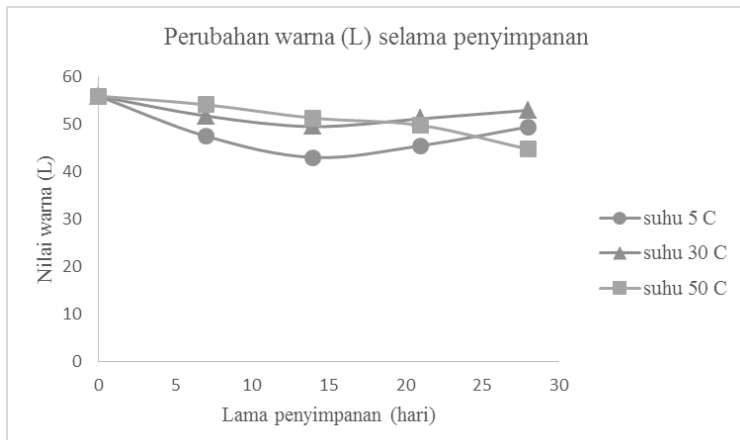

Gambar 2. Grafik perubahan warna sirup selama penyimpanan

Gambar 2 menunjukkan adanya perubahan warna pada produk sirup selama penyimpanan. Warna sirup menjadi semakin gelap dikarenakan adanya reaksi Maillard. Reaksi Maillard yaitu reaksi antara gugus amino dari suatu asam amino bebas residu rantai peptida atau protein dengan gugus karbonil dari suatu karbohidrat apabila keduanya dipanaskan atau penyimpanan dalam waktu lama (Lakshmi, 2014). Analisis dilakukan sebelum sirup disimpan (hari ke 0 ). Hasil analisis ini dianggap sebagai nilai karakteristik awal sirup. Nilai karakteristik akhir sirup didapatkan dari hasil analisis pada hari ke 28 dalam setiap suhu. Parameter Arrhenius dari hasil analisis perubahan warna sirup dapat dilihat pada Tabel 1.

Tabel 1. Parameter Arrhenius perubahan

\begin{tabular}{llll}
\multicolumn{4}{c}{ warna sirup } \\
\hline $\mathbf{T}(\mathbf{K})$ & $\mathbf{1 / T}$ & $\mathbf{k}$ & $\mathbf{I n ~ k}$ \\
\hline 278 & 0,0036 & 0,2136 & $-1,5436$ \\
303 & 0,0033 & 0,0933 & $-2,3719$ \\
323 & 0,0031 & 0,3769 & $-0,9758$ \\
\hline
\end{tabular}

Nilai $1 / T$ dan In $\mathrm{k}$ diplotkan sehingga akan didapatkan grafik hubungan antara lama penyimpanan dengan perubahan warna sirup yang dapat dilihat pada Gambar 3.

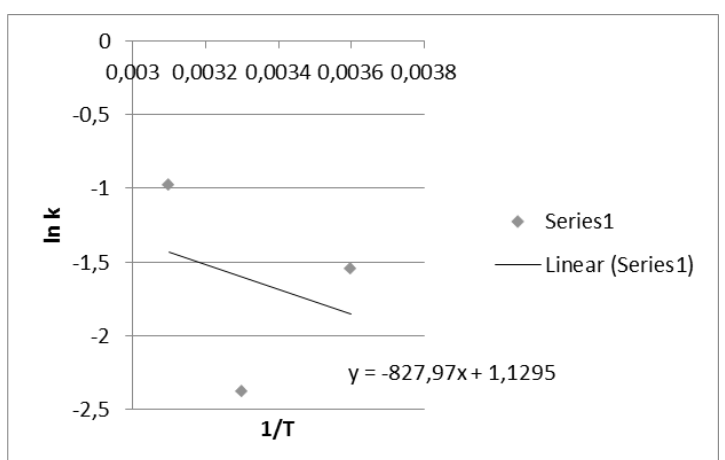

Gambar 3. Grafik perubahan warna (In k) terhadap suhu penyimpanan $(1 / T)$
Pro Food (Jurnal IImu dan Teknologi Pangan)

Vol 4 No. 1 Mei 2018

ISSN: 2443-1095

Persamaan regresi linier yang didapatkan dari plot $1 / T$ dengan In $\mathrm{k}$ adalah:

$$
y=-827,97 x+1,1295
$$

dari persamaan di atas diperoleh energi aktivasi sebesar $1664,35 \mathrm{kal} / \mathrm{mol}$, yang artinya bahwa besarnya energi minimal yang dibutuhkan molekul dalam sirup untuk merubah warna sirup sebesar 1664,35 $\mathrm{kal} / \mathrm{mol}$.

\section{Analisis pH}

Hasil analisis $\mathrm{pH}$ sirup dengan tiga suhu penyimpanan yang berbeda selama 28 hari dapat dilihat pada Gambar 4. pH selama penyimpanan cenderung mengalami penurunan pada suhu rendah dan suhu ruang dikarenakan terbentuknya asam lemah oleh aktivitas mikrobia (Aulia, 2017).

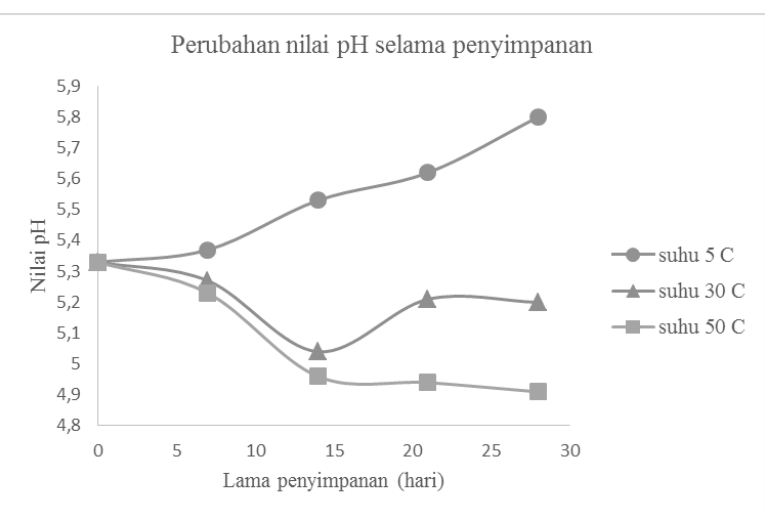

Gambar 4. Grafik perubahan nilai pH sirup selama penyimpanan

Analisis dilakukan sebelum sirup disimpan (hari ke 0) hingga hari ke 28 dalam setiap suhu. Parameter Arrhenius dari hasil analisis perubahan nilai $\mathrm{pH}$ sirup dapat dilihat pada Tabel 2.

Tabel 2. Parameter Arrhenius perubahan warna sirup

\begin{tabular}{llll}
\hline $\mathbf{T}(\mathbf{K})$ & $\mathbf{1 / T}$ & $\mathbf{k}$ & $\mathbf{I n ~} \mathbf{k}$ \\
\hline 278 & 0,0036 & 0,017 & $-4,0745$ \\
303 & 0,0033 & 0,0046 & $-5,3817$ \\
323 & 0,0031 & 0,0161 & $-4,1289$ \\
\hline
\end{tabular}

Nilai $1 / T$ dan In $\mathrm{k}$ diplotkan sehingga akan didapatkan grafik hubungan antara lama penyimpanan dengan perubahan nilai $\mathrm{pH}$ sirup yang dapat dilihat pada Gambar 5. 
Versi Online:

http://www.profood.unram.ac.id/index.php/profood e-ISSN: 2443-3446

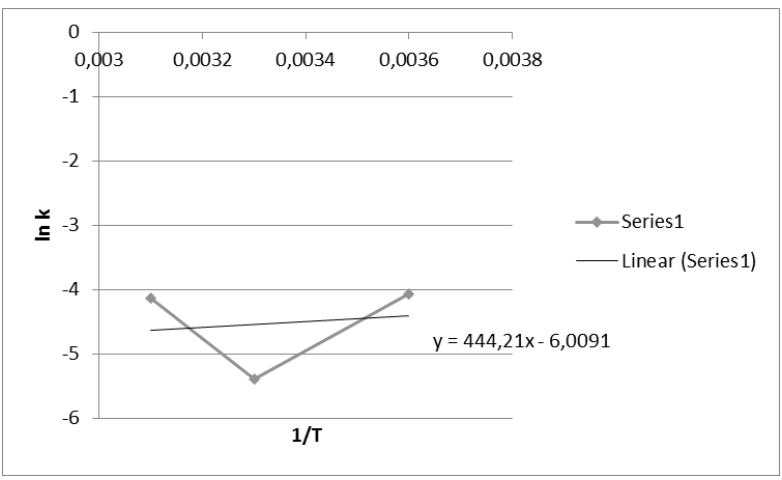

Gambar 5. Grafik perubahan nilai pH (In k) terhadap suhu penyimpanan $(1 / \mathrm{T})$

Persamaan regresi linier yang didapatkan dari plot $1 / \mathrm{T}$ dengan In $\mathrm{k}$ adalah:

$$
y=444,21 x-6,0091
$$

dari persamaan di atas diperoleh energi aktivasi sebesar 882,201 kal/mol, yang artinya bahwa besarnya energi minimal yang dibutuhkan molekul dalam sirup untuk mengubah nilai pH sebesar 882,201 kal/mol.

\section{Analisis Kadar Gula Reduksi}

Hasil analisis kadar gula sirup dengan tiga suhu penyimpanan yang berbeda selama 28 hari dapat dilihat pada Gambar 6.

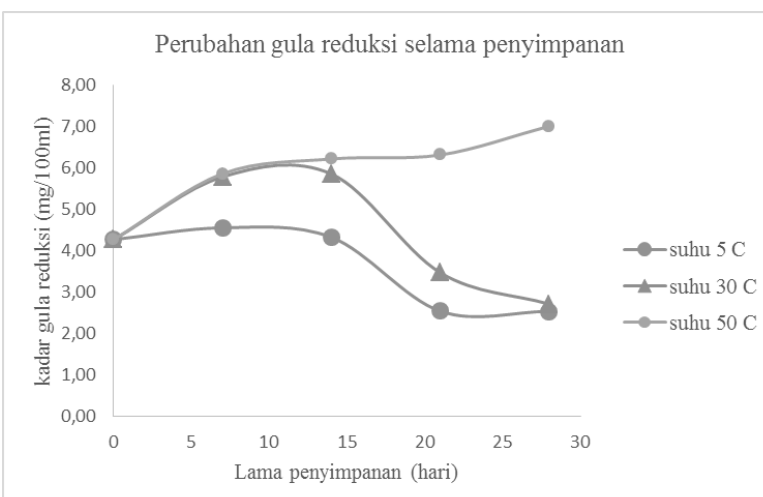

Gambar 6. Grafik perubahan kadar gula sirup selama penyimpanan

Analisis dilakukan sebelum sirup disimpan (hari ke 0) hingga hari ke 28 dalam setiap suhu. Parameter Arrhenius dari hasil analisis perubahan kadar gula sirup dapat dilihat pada Tabel 3.

Tabel 3. Parameter Arrhenius perubahan kadar gula sirup

\begin{tabular}{llll}
\hline $\mathbf{T}(\mathbf{K})$ & $\mathbf{1 / T}$ & $\mathbf{k}$ & $\mathbf{I n ~ k}$ \\
\hline 278 & 0,0036 & 0,0783 & $-2,5472$ \\
303 & 0,0033 & 0,0777 & $-2,5549$ \\
323 & 0,0031 & 0,0848 & $-2,4675$ \\
\hline
\end{tabular}

Nilai $1 / T$ dan In $\mathrm{k}$ diplotkan sehingga akan didapatkan grafik hubungan antara lama penyimpanan dengan perubahan kadar gula sirup yang dapat dilihat pada Gambar 7.

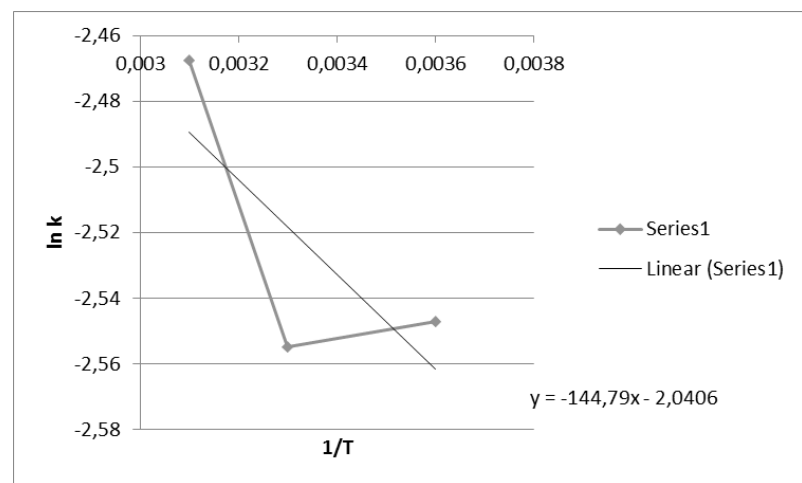

Gambar 7. Grafik perubahan nilai kadar gula (In k) terhadap suhu penyimpanan $(1 / \mathrm{T})$

Persamaan regresi linier yang didapatkan dari plot 1/T dengan In $\mathrm{k}$ adalah:

$$
y=-144,79 x-2,0406
$$

dari persamaan di atas diperoleh energi aktivasi sebesar 287,55 kal/mol, yang artinya bahwa besarnya energi minimal yang dibutuhkan molekul dalam sirup untuk mengubah kadar gula sebesar 287,55 kal/mol.

\section{Penentuan Umur Simpan Sirup Buah Tin}

Nilai energi aktivasi menjadi pertimbangan dalam pemilihan parameter yang akan dijadikan acuan dalam pengukuran umur simpan. Parameter yang digunakan tersebut adalah parameter yang mempunyai nilai energi aktivasi terendah. Energi aktivasi yang rendah dapat diartikan bahwa energi untuk memulai reaksi juga rendah, sehingga reaksi kerusakan akan berlangsung lebih lama. Jika energi aktivasi tinggi, energi yang dibutuhkan untuk memulai reaksi kerusakan lebih tinggi dan berlangsung lebih cepat (Estiasih, 2010). Nilai gula reduksi menunjukkan energi aktivasi terendah seperti terlihat pada Tabel 4.

Tabel 4. Energi aktivasi parameter mutu sirup buah tin

\begin{tabular}{ll}
\hline Parameter mutu & $\begin{array}{l}\text { Nilai energi aktivasi } \\
\text { (kal/mol) }\end{array}$ \\
\hline Warna & 1644,35 \\
Nilai pH & 882,201 \\
Kadar gula reduksi & 287,55 \\
\hline
\end{tabular}

Berdasarkan parameter kadar gula reduksi, diperoleh umur simpan sirup selama 
19 hari pada suhu penyimpanan $30^{\circ} \mathrm{C}$ dan 22 hari pada suhu $5^{\circ} \mathrm{C}$. Umur simpan sirup buah tin ini lebih rendah dibandingkan perhitungan produsen. Hal ini disebabkan karena tanpa penambahan bahan pengawet kimia dan proses produksi yang masih manual sehingga tingkat higienitas selama produksi hingga pemasaran belum terjamin. Selain itu perbedaan cara pengukuran umur simpan juga akan berpengaruh terhadap hasil.

Penentuan umur simpan sirup ini dengan mengggunakan metode ASLT dimana menggunakan parameter baik secara kimia maupun fisik. Posdaya Lancar Barokah menguji umur simpan produk sirup dengan uji organoleptik yang dilakukan oleh produsen. Kelemahan metode ini adalah belum adanya panelis ahli. Hal ini akan menyebabkan subyektivitas panelis dalam menilai rasa dan penampakan sirup. Penentuan umur simpan tidak hanya dapat dilakukan menggunakan satu metode, yaitu organoleptik tetapi merupakan gabungan hasil dari analisis secara kimia, fisik dan oranoleptik (Anagari dkk, 2011).

\section{KESIMPULAN}

Sirup buah tin dengan penyimpanan di tiga suhu yang berbeda selama 28 hari mengalami perubahan warna, $\mathrm{pH}$ dan kadar gula. Perubahan kadar gula mempunyai energi aktivasi terendah yaitu sebesar 287,55 $\mathrm{mol} / \mathrm{kal}$ sehingga digunakan sebagai kriteria penentu umur simpan. Umur simpan sirup buah tin berdasarkan dari perubahan kadar gula yaitu selama 19 hari di suhu ruang dan 22 hari di suhu rendah.

\section{DAFTAR PUSTAKA}

Afriyanti, Asmoro NW. 2017. Pendugaan umur simpan sirup buah semu jambu mete (Anacardium occidentale, L) dengan metode accelerated shelf life testing (ASLT). Agrisaintifika 1(2) Desember 2017.

[AOAC] Association of Official Analytical Chemist. 1995. Official Methods of Analysis of The Association of Official Analytical Chemist. Arlington (VG): AOAC Inc.

Anagari, Hesti. 2011. Penentuan Umur Simpan Minuman Fungsional Sari Akar Alang-alang dengan Metode Accelerated Shelf Life Testing (ASLT)
(Studi Kasus di UKM "R Rovit" Batu, Malang). Agrointek, 5(2).

Apriyantono A, Fardiaz D. Puspitasari NL dan Budianto S. $1989 . \quad$ Petunjuk Laboratorium Analisa Pangan. Depdikbud Dirjen Pendidikan Tinggi PAU Pangan dan Gizi. IPB, Bogor

Aryani, Ghesi W. 2013. Pendugaan Umur Simpan dengan Metode Accelerated Shelf Life Testing (ASLT) pada Produk Bandrek Instan dan Sirup Buah Pala (Myristica fragrans, Houtt) di Desa Sinarsari dan Dramaga Kabupaten Bogor. [Skripsi]. Bogor: Fakultas Teknologi Pertanian, Institut Pertanian Bogor.

Aulia, Annisa. 2017. Pengaruh Waktu Penyimpanan terhadap $\mathrm{pH}$ Sediaan Obat Kumur Ekstrak Bunga Delima Merah (Punica granatum L). [Skripsi]. Surakarta: Fakultas Kedokteran Gigi Universitas Muhammadiyah Surakarta.

Estiasih T. 2010. Penentuan umur simpan jahe instan dengan metode accelarated shelf life test (ASLT) dengan pendekatan Arrhenius. Malang (ID): Universitas Brawijaya.

Hutching JB. 1999. Food Color and Appearance. Chapman and Hall Food Science Book. Aspen Publishers, Inc., Gaithersburg, Maryland.

Labuza, T.P and Riboh, D. 1982. Theory and Application of Arrhenius Kinetics to the Prediction of Nutrien Losses in Food. Food Technology 36: 66-74

Lakshmi, Chaitanya. 2014. Food Coloring: The Natural Way. Research Journal of Chemical Sciences 4(2): 87-96.

Pranoto, Marseno, Haryadi. 2012. Perkiraan Umur Simpan Kacang Rendah Lemak Dilapisi dengan Carboxymethyl Cellulose Menggunakan Metode Accelerated Shelf-Life Test (ASLT). Agritech Vol 32 No 3 Agustus 2012

Pratiwi. 2009. Formulasi, Uji Kecukupan Panas dan Pendugaan Umur Simpan Minuman Sari Wornas (Wortel-Nanas). Skripsi. Fakultas Teknologi Pertanian, Institut Pertanian Bogor. Bogor.

Riyadi, Bharsela. 2018. Usaha Olahan Sirup Buah Tin Berkhasiat Masih Terbuka Lebar. http://pokohkidul.desa.id/2018/01/30/u 
Versi Online:

http://www.profood.unram.ac.id/index.php/profood e-ISSN: 2443-3446

saha-olahan-sirup-buah-tin-berkhasiatmasih-terbuka-lebar/ [28 April 2018].

Suwita, Komang. 2012. Pendugaan Umur Simpan Sirup Temulawak (Curcuma xanthorrhiza Roxb), Madu dan Ekstrak Ikan Gabus (Ophiocephalus striatus) dengan Model Arrhenius dan Model $\mathrm{Q}_{10}$. [Skripsi]. Politeknik Kesehatan Kemenkes. Malang.

menk. 